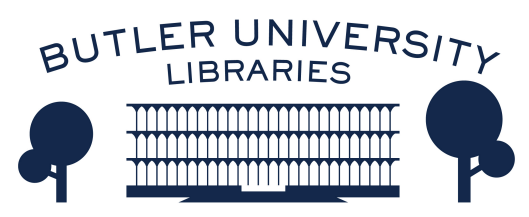

Journal of Hindu-Christian Studies

Volume 14

Article 9

January 2001

\title{
Hindu Bioethics for the Twenty-First Century
}

S. Cromwell Crawford

Follow this and additional works at: https://digitalcommons.butler.edu/jhcs

Part of the Religion Commons

\section{Recommended Citation}

Crawford, S. Cromwell (2001) "Hindu Bioethics for the Twenty-First Century," Journal of Hindu-Christian Studies: Vol. 14, Article 9.

Available at: https://doi.org/10.7825/2164-6279.1252

The Journal of Hindu-Christian Studies is a publication of the Society for Hindu-Christian Studies. The digital version is made available by Digital Commons @ Butler University. For questions about the Journal or the Society, please contact cbauman@butler.edu. For more information about Digital Commons @ Butler University, please contact digitalscholarship@butler.edu. 


\title{
Hindu Bioethics for the Twenty-First Century
}

\author{
S. Cromwell Crawford \\ University of Hawaii
}

\section{Introduction}

IN his Cross Cultural Perspectives in Medical Ethics: Readings, Robert Veatch observes, "The religions of Judaism and Christianity and the secular thought of the political philosophy of liberalism in the Anglo-American West are not the only alternatives to a Hippocratic medical ethic.".1 In fact, the new pluralistic approach to world cultures is introducing us to several religious and philosophical alternatives from outside the Anglo-American West. Just as alternative medicine is becoming recognized and respected, and is being incorporated into mainstream medicine, there is a growing admission that the ethical problems we face today have dimensions that are not adequately addressed by the standard responses of Judaism, Christianity, and secular philosophies. From among these new Eastern perspectives, Hindu bioethics stands out. Its strength lies in the fact that it is integrated in an indigenous system of medicine, and is more alive today than at any time in its 2000 year history. It addresses the preventive and promotive aspects of medicine; mind-body connections; connections between the microcosmos and macrocosmos; and relies solely on nature. In addition to this scientific orientation, Hindu bioethics is philosophically pluralistic and ethically contextual, giving it that conceptual flexibility which is often missing in its Western religious counterparts, but which is demanded by the complexities of contemporary issues. All this proceeds from the focus of Hindu bioethics on the person as a composite of somatic, psychic, social and spiritual dimensions. In this piece, we focus on these three distinctive features of Hindu bioethics, namely: its medical basis; its philosophical framework; its ethical orientation.

\section{Distinctive Features of Hindu Bioethics}

\section{Medical Basis}

A unique feature of Hinduism is that a fully fledged system of medicine evolved within its complex ethos. The historical developments are shrouded in mystery due to their long antiquity. Yet, inasmuch as all primitive societies have survived by recourse to some rudimentary system of medicine, it is fair to assume that during the protohistoric Harappa Culture, which preceded and followed 2000 B.C., a rudimentary system of medicine was practised in the northwestern region of India. Archaeological excavations at the two main capitals of Harappa and Mohenjo-daro give evidence of a technically advanced society that built its houses, streets, and public facilities with a knowledge of the principles of good hygiene and sanitation. Water was valued for its purifying and therapeutic qualities. Terra cotta figurines and images on seals, suggest powerful sentiments for Mother Earth and her bounty of plants and animals. The figure of a horned deity, ritualistically seated in a yogic position, typifies an ancient medicine-man. The Harappa Culture collapsed by around 1500 B.C.E.

Data covering the end of the second millennium B.C.E. are drawn from the Rg Veda, the earliest literature of India, which gives us clearer glimpses of the state of medicine in the early Vedic period. More important than the Rg Veda for knowledge 
of ancient Indian medical lore are the hymns of the Atharva, which should be read with the Kausikasutra.

Vedic medicine was predominantly magico-religious, but mixed in with sorcery and witchcraft are certain empirical facets of healing. These procedures include surgery; methods for stopping hemorrhage; bonesetting; hydrotherapy; and extensive use of plants and herbs. Underlying a good deal of the ritualistic actions is a clever use of the power of suggestion and visualization. ${ }^{2}$

During the millennium preceding the Christian era, developments take place which precipitate a paradigm shift from the earlier magico-religious tradition to the new empirico-rational medicine of Ayurveda. In his Asceticism and Healing in Ancient India (1991), Kenneth G. Zysk traces the contribution made by Buddhism to Indian medicine through its institutionalization in monasteries, which led to new models for medical manuals; through the emergence of monk-healers; and through the establishment of monastic hospices and infirmaries. During the Gupta period, Zysk states "Hinduism assimilated the ascetic medical repository into its socioreligious and intellectual tradition," thus making it an orthodox Hindu science. ${ }^{3}$

Ayurveda is "the science of (living to a ripe) age." The term is semantically significant. Basham notes: "its first component (ayur) implies that the ancient Indian doctor was concerned not only with curing disease but also with promoting positive health and longevity, while the second (veda) has religious overtones, being the term used for the most sacred texts of Hinduism." 4

The standard texts on Ayurveda are certain extant collections known as The Great Trio (Brhat-Trayi). They are (i) the Caraka Samhita (100 A.D.), (ii) the Susruta Samhita (3-4 A.D.), and (iii) Vagbhata's Astangahrdayam (med-7 A.D.).

Ayurveda is divided into eight branches: (1) Internal Medicine; (2) Surgery; (3) Diseases of the Supraclavicular area; (4) Pediatrics, including Obstetrics/Gynaecology; (5) Toxicology; (6)
Psychiatry; (7) . Rejuvenation;

Knowledge for increase of virility.

One is impressed by the range of topics the medical manuals of Ayurveda cover, reading almost like modern medical texts, notwithstanding their antiquity, and also for their concern for the moral dimensions of medicine. This orientation bodes well for our attempt to construct a distinctive system of Hindu bioethics.

This symbiosis between medicine and morals follows from common assumptions which underlie both disciplines. We here highlight some of the salient features of Indian medicine which provide the bases for ethical analysis:

(1) Ayurveda is rational in its approach to medicine. In place of the supernatural therapy (daivavyapasraya) of the Vedic phase, it introduced rational therapy (yuktivyapasraya) to make the system logical and scientific.

(2) Ayurveda is holistic. It views the person as an integrated whole and not just an aggregate of several body parts that are the domain of specialists.

(3) Ayurveda sees the person as grounded in nature: a microcosm within the macrocosm. Diet, climate, soil, season, time and place are all factors with which to reckon.

(4) Health and healing are regarded as acts of nature. In medico-ethical terms: the natural is the good.

(5) Health is identified as a positive state, and not just the absence of disease.

(6) Health is multi-dimensional: physical, mental, social and spiritual.

(7) Ayurveda apprehends the person as an individual, having a unique constitutional type, and as the bearer of an unmatched set of life experiences.

(8) Ayurveda gives prominence to the notion of balance. It promotes an ethics of moderation in matters of sex and abstinence, food and drink, work and play, sleeping and awaking, faith and common sense.

(9) Medicine is essentially preventive and promotive, elevating caring above curing. 
(10) Longevity is measured not in number of days, but quality of time.

(11) Death is an inevitable part of the natural process, and is therefore not an evil or the object of divine punishment. Death is the opposite of birth, not of life.

(12) Health and disease, happiness and suffering, life and death are the consequences of an individual's karma, hence the emphasis on human responsibility.

(13) Health is more than what the doctors do; it is a total life-style that carries one from cradle to the grave.

(14) Health is not the ultimate good but the penultimate good.

The moral structure of Indian medicine makes it eminently suited to deal with the dilemmas which arise in modern medical practice.

\section{Philosophic Framework}

Next we explore how the integration of the religio-philosophic speculations of Ayurveda, along with other schools of Indian philosophy, give Indian medicine a distinctive shape. Ayurveda is a compendium of science and philosophy. As a science its purpose is to ensure health of body and mind; as a philosophy its goals go beyond the preservation of health and the curing of disease. The present resurgence of Ayurveda in the West is as much due to its philosophy as its science, because it appeals to the felt need for a more humanistically oriented approach to medicine.

Eminent philosopher, Surendranath Dasgupta, raises the issue as to whether the speculations in the medical schools deserve to be included in a history of Indian philosophy - subject of the magnum opus he was writing. In his judgment any objection loses its force when it is remembered that "medicine was the most important of all the physical sciences which were cultivated in ancient India, was directly and intimately connected with the Samkhya and Vaisesika physics and was probably the origin of the logical speculations subsequently codified in the Nyaya-sutras." $\mathrm{He}$ proceeds to point out that the medical literature embodies a vision of life that is supported by interesting ethical instructions not present in works of philosophy. The manuals also cover many other interesting details which "throw a flood of lights on the scholastic methods of Indian thinkers." Moreover, scholars in touch with "the importance of Hatha Yoga or Tantra physiology or anatomy in relation to some of the Yoga practices of these schools will no doubt be interested to know for purposes of comparison or contrast the speculations of the medical schools on kindred points of interest." Dasgupta concludes his case for the inclusion of the medical literature in his History of Indian Philosophy by arguing that even "a student of pure philosophy" will find intriguing the medical speculations regarding "embryology, heredity and other points of general enquiry."

Dasgupta's remarks highlight the fact that the development of medicine in India has gone hand in hand with the development of philosophy. The reason for this is that Indian philosophy is more than intellectual curiosity, it is the quest for the elimination of moral and physical suffering that characterizes all of human existence. The goal of philosophy is to liberate the human consciousness to its native level of being; and sound health is both the condition and creation of this philosophical end. This inclusion of knowledge and wisdom with the path to attain liberation has distinguished Indian philosophy as a way of life and not merely as a way of thought. The most characteristic path prescribed for reaching liberation has been a cultivation of the spirit of renunciation. The progressive practice of renunciation internally produces peace of mind and externally transforms behaviour. This gradually produces empathy for all sentient beings, as embodied in the principle of ahimsa, which enjoins that we do no harm.

Additionally, the inclusion of diverse philosophic viewpoints imparts to Indian medicine a pluralistic stance, quite necessary for doing bioethics in a multi-cultural setting. 


\section{Ethical Orientation}

Most importantly, Hindu bioethics is unique, because of the contextual structure of Hindu ethics.

Any survey of clinical cases reveals that dilemmas lie at the heart of bioethics. For its part, Hindu ethics is a moral system which acknowledges genuine moral dilemmas. We encounter a dilemma when values to which we are equally committed are brought into conflict, so that the honouring of one value necessitates the violation of the other. The Hindu position in this regard is to be distinguished both from that of the religious fundamentalist, who views dilemmas in the light of revelation, and of the secular rationalist, who views them as problems to be solved by the use of reason. For the religious fundamentalist, the problem is the need for a better faith; for the secular rationalist, it is the need for superior knowledge. In either case, there are no genuine dilemmas.

In Hinduism dilemmas are not denied. Its scriptures strain with the tension of irreconcilable alternatives. The best examples are found in the epic literature. The Mahabharata and the Ramayana are not just works of antiquity but embody the social sinew which connects past with present and makes the epics dateless treasures of true dilemmas. This point is adequately illustrated by the late Bimal $\mathrm{K}$. Matilal in his Moral Dilemmas in the Mahabharata.

The internal flexibility of Hindu ethics when dealing with "duties in distress," gives it a certain advantage over two extreme positions on the current social spectrum, dealing with life-and-death issues.

First there is the position of Authoritarianism. It surfaces in different degrees in the moral stance of religious groups such as the Roman Catholic Church, Protestant fundamentalists, Mormons, Jehovah's Witnesses, and in quasi-religious organizations as Operation Rescue. These groups base their truth claims on holy books and sacrosanct traditions in which they find objectively valid norms of conduct. They see human reason as flawed, and therefore rely on revelation for the full truth. Reason may be resorted to, but only as hand-maiden to revelation. This makes them tend to see moral issues in terms of black and white, and therefore to have little tolerance for exceptional cases, or the demands of particular situations.

At the opposite end of the spectrum is the position of Relativism. Relativists argue that value judgments and ethical norms are reducible to matters of subjective preference, and therefore questions of life and death are considered private issues to be answered by each individual. They, too, minimize the capacity of reason. With hedonic overtones, Relativists make the individual's own experience of happiness the standard of value, worthy of protection by the American constitution.

Hindu ethics is distinguished from both extremes by the importance it gives to rational authority. This claim may be queried, because of the part played by revelation within its own system. However, Hinduism's recognition of revelation as a conduit of knowledge does not depreciate the role of reason. The Hindu sastras make a liberal use of reason in support of the positions they take in ethical and other matters. Only the final validity of reason is questioned in mystical matters which lie beyond its purview. Thus the admission of revelation does not prejudice reason, for there is continuity between the two. Whereas in Western thought revelation is an external mode of testimony, in Hindu perspective revelation is an internal activity, similar to intuition, as Hiriyanna has argued.

Through reason and intuition, Hinduism finds the source of ethics in the nature of the person, holistically perceived. It agrees with the Relativists that the claims of Authoritarianism to finding absolute values is illusory and pretentious, because social morality is inevitably the construct of subjective, historical forces that reflect the accidents of time and place; but the admission of subjectivity is not tantamount to saying that all our choices between life and death are merely the products of 
subjective tastes and preferences. To the contrary, we can arrive at objectively valid norms based on our knowledge of deepseated human capacities for life, for love, for freedom, and for integrity, which are articulated as samanya or generic duties. Our cultural formulations of these psychic striving will always be relative, constantly to be refined over the long haul of human experience - which is to acknowledge that objectivity is not absolute or unconditional. The notion of absolutism is alien to Hindu ethics, because it is a concept of transcendental revelation that is removed from an appreciative understanding of human nature and human history.

This approach imparts to Hindu bioethics an orientation of moral reasoning in its dealing with moral problems. It eschews the path of authoritarianism, creedalism, emotionalism, and takes the road of rationality. However, it is not the rationality of the disembodied mind, but the rationality of the whole person. The autonomous individual gives due weight to scriptural injunctions and the precedents of persons of probity, but in the final analysis, he/she turns to the dictates of conscience, making that person responsible for his or her own karma.

These considerations mean that a premium is placed on individual conduct, developed in the scheme of sadvrtta. Caraka says: "In order to prevent derangements in sense organs along with mind one should make effort to maintain the normalcy of these methods - such as, with conjunction of wholesome sense objects one should perform acts well properly and invariably examining with intellect, and also by regular use of those which are opposite to the qualities of place, time and self. Hence, one who desires to promote his own well-being should follow the entire code of good conduct fully, invariably and cautiously."7 Along the same lines, Caraka cautions against prajnaparadha (intellectual error) in respect to the harmful actions of speech, mind and body.

Thus, whereas Christian bioethics works within a supernatural framework in which the issues of health and disease must reckon with divine or demonic agency, Hindu bioethics holds the individual responsible and gives preventive medicine a moral status. Given the goal of life as moksa, the individual is under obligation to maintain physical and mental fitness in order to facilitate that end. This is not to say that Christians are not held responsible for their state of health, but that the degree to which the will of God or the wiles of the devil are insinuated, freedom is rendered ambiguous and responsibility is compromised, albeit for a divine purpose (punishment, test, trial, education, edification expiation).

Notwithstanding its claim to rationality, Hindu bioethics acknowledges that persons of reason might not always agree on what is good, but they can agree more generally on what is evil. Rational people wish to avoid for themselves and for their loved ones evils such as pain, disease, premature death, and the loss of abilities to pursue the purusarthas. Therefore, while promoting the good, the basic agenda of Hindu bioethics is to prevent evil by advocating principles and proscriptions against behaviour that inflicts harm to persons and to all sentient creatures. Its bottom line, based on the cardinal value of ahimsa, is: Do no harm - himsam ma kuru.

Hindu ethical principles are applied to two areas: Issues at the Beginning of Life, and Issues at the End of Life.

Issues at the Beginning of Life are: Technology and the Womb; Dilemmas at Birth; When Parents Let Children Suffer for Reasons of Faith; Ethics of Contraception; Ethics of Abortion; Ethics of Pre-Natal Diagnosis for Sex Selection; Ethics of the Human Genome Project; Ethics of Cloning; Ethics of Population Growth.

Issues at the End of Life are: Ethics of Suicide; Ethics of Euthanasia; Ethics of Aging; Ethics of Death and Dying.

\section{Notes}

1. Robert M. Veatch, Introduction, Cross Cultural Perspectives in Medical 


\section{Cromwell Crawford}

Ethics: Readings, Robert M. Veatch, ed. (Boston: Jones and Bartlett Publishers, 1989), p. 96.

2. Henry R. Zimmer, Hindu Medicine (Baltimore: The Johns Hopkins Press, 1948), p. 9f.

3. Kenneth G. Zysk, Asceticism and Healing in Ancient India (New York: Oxford University Press, 1991), p. 118.

4. A.L. Basham, "The Practice of Medicine in Ancient and Medieval India," in Asian Medical Systems: A
Comparative Study, Charles Leslie, ed. (Berkeley: University of California Press, 1976), p. 18.

5. Surendranath Dasgupta, A History of Indian Philosophy (2 Vols; Cambridge: Cambridge University Press, 1968), Vol 2, p. 273.

6. Caraka Samhita, Priyavrat Sharma, ed.-trans. (3 Vols; Varanasi: Chaukhamba Orientalia, 1981), Vol. 1, Sutrasthana V111.17, p. 56.

7. Ibid. 1X.41. 